\title{
GOVERNMENT DOMINATION IN ANTARA TV THE FEATURE NEWS PRODUCTION PROCESS OF "MATA INDONESIA"
}

\author{
Oleh:
}

\author{
Abdul Kholik
}

\begin{abstract}
The Ministry of Communication and Informatics has the task to distribute information on the various state activities, social and other community activities. The task of producing and disseminating this information is given to a Public Company of National News Agency (LKBN/Lembaga Kantor Berita Nasional) Antara. The research was carried out with a qualitative approach with the research of the feature news Antara $T V$, Mata Indonesia as an object. The study was conducted by performing a direct observations on the production process of the feature news Mata Indonesia. In the Mata Indonesia production process the Ministry has a dominant role in determining the direction and policy of Mata Indonesia. With economic and political power, the Ministry has intervened since the production designs, production processes in the field and regulate the final output of Mata Indonesia. To still be able to produce Mata Indonesia, the editor of Antara TV applies the gatekeeper function. Where all elements involved in selecting information will be presented.
\end{abstract}

Keywords: media political economy, gatekeeper, journalistic tv, feature news

\begin{abstract}
ABSTRAK
Kementerian Komunikasi dan Informatika memiliki tugas menyebarkan informasi berbagai kegiatan kenegaraan, kepemeritahan serta kemasyarakatan lainnya. Tugas produksi dan penyebaran informasi ini diserahkan kepada Perusahaan Umum Lembaga Kantor Berita Nasional (LKBN) Antara. Penelitian dilakukan dengan pendekatan kualitatif dengan objek penelitian berita feature Antara TV, Mata Indonesia. Penelitian dilakukan dengan melakukan observasi langsung terhadap proses produksi Mata Indonesia. Untuk memperdalam informasi, peneliti mengumpulkan berbagai data dari redaksi Antara TV, serta melakukan wawancara. Hasil penelitian menemukan dengan kuasa ekonomi dan politik, Kementerian Kominfo melakukan intervensi sejak dari penyusunan rencana liputan, proses produksi hingga hasil akhir produk Mata Indonesia. Untuk tetap dapat memroduksi, redaksi Antara TV menerapkan fungsi gatekeeper. Di mana semua unsur yang terlibat melakukan seleksi terhadap informasi yang akan disajikan.
\end{abstract}

Kata Kunci: ekonomi politik media; gatekeeper; jurnalistik tv; berita feature

Program Studi Ilmu Komunikasi Institut Bisnis dan Informatika Kwik Kian Gie. Jl. Yos Sudarso Kav.87, Sunter, Jakarta Utara 14350. abdul.kholik@kwikkiangie.ac.id 


\section{INTRODUCTION}

Information is a driving factor in protecting the quality of life of the community. With adequate access and availability of information, everyone will be able to develop themselves and their standard of living. Provision of information is a constitutional mandate. The government has an obligation to ensure that every Indonesian society in all corners Indonesia gets quality information according to their needs.

The Ministry of Communication and Information Technology has the task of carrying out government affairs in the field of communication and information technology. The Ministry of Communication and Information has the task of disseminating information on various state, community and other social activities. This information dissemination is also a counterweight to framing by other mass media. The task of producing and disseminating this information is submitted by the Ministry of Communication and Information to the Public Company, the National News Agency (LKBN) Antara through the implementation of the Public Service Obligation (PSO) for Public Information in the Press Sector.

The assignment to Antara was carried out based on Government Regulation Number 40 of 2007 concerning Public Companies, Antara National News Agency Institutions and Law Number 19 of 2003 concerning State-Owned Enterprises. This assignment is one of the government's efforts to ensure the availability and access of information for people throughout Indonesia, especially in disadvantaged, frontier and remote areas.

PSO for the Press or news PSO is the government's effort to serve and fulfill the people's rights, especially in fulfilling the need for information. The information presented through the PSO for the Press Sector cannot be separated from every effort of the national elements in caring for the national interest. Information in the PSO for the Press cannot be separated from the government's plans, programs and performance.
Many efforts have been made by the government to carry out development in an effort to improve people's welfare. The government's steps and efforts need to be widely known by the public. Thus, more massive socialization, advocacy and campaign efforts are needed so that the public is not only aware of but also actively participates in every government program.

The assignment to Antara has been going on since 2008. The PSO framework for the Press is aimed at producing and disseminating or disseminating public information that educates, enlightens, empowers and strengthens the Unitary State of the Republic of Indonesia. Information through the PSO for the Press does not only channel and report the aspirations of the community. More than that, it is necessary to prioritize non-sensational, non-bombastic, educational, enlightening, empowering information.

To achieve these aims and objectives, Antara organizes production activities and disseminates public information on various agendas for state, government and community activities at the national, regional and international levels.

In carrying out its duties as the National News Agency, Antara continues to uphold journalistic principles. In carrying out its duties as the National News Agency, Antara continues to uphold journalistic principles. In addition to presenting news that is fast, accurate and important, Antara holds the $3 \mathrm{E} 1 \mathrm{~N}$ principles, namely Educating (educating), Enlightening (enlightening), Empowering (empowering) and Nationalism (nationality). This principle is held by Antara to build a good and smart community, nation and state life. In addition, in the current millennial era, Antara is also required to produce information that is informative, popular and easily accepted by the public, especially millennials. One of the PSO news that was produced was the feature of Mata Indonesia which was produced by Antara TV.

In the production process of Mata Indonesia, Antara is accompanied by the Ministry of Communication and Information as the 
technical ministry. The Ministry of Communication and Information has an interest in assisting Antara in the production process, so that the news produced is in accordance with the interests of the government, namely spreading positive, optimistic reality news, while maintaining the $3 \mathrm{E} 1 \mathrm{~N}$ principles.

Indonesia's eyes should be a counterweight in facing the media framing. Where there is an imbalance between horror news, violence, sex, gossip, and glamor with inspirational news containing $3 \mathrm{E} 1 \mathrm{~N}$. However, in its implementation, the Indonesian Eye is filled with information about government activities, the success of the government in implementing its programs, as well as various information about activities that have been, are currently and will be carried out by the government.

Based on the background of the problem, the researcher conducted research with the following problem formulations:

1) How is the dominance of the Ministry of Communication and Informatics in the production of the Mata Indonesia feature program?

2) How is Antara TV editorial strategy in producing Mata Indonesia feature program?

Meanwhile, the expected goal of this research is to understand how much government dominance, in this case the Ministry of Communication and Information Technology, as well as the editorial strategy of Antara TV in the production process of Mata Indonesia's feature news.

In this study, the authors used a critical paradigm. Critical theory was born as a correction to the view of constructivism which is less sensitive to the processes of production and reproduction of meaning that occur historically or institutionally. Critical theory analysis is not focused on the truth / untruth of grammatical structures or the interpretive process as in constructivism. Critical analysis emphasizes the constellation of forces that occur in the process of production and reproduction of meaning. Individuals are not considered as neutral subjects who can interpret them freely according to their thoughts, because they are closely related and influenced by social forces that exist in society. Analysis is used to uncover the power that exists in every communication process (Ardianto, 2014).

The critical paradigm is a knowledge paradigm that "always suspects" there is an interest behind something. Almost all social theories in this paradigm have practical implications and intentions and influence social change. This paradigm not only criticizes the injustice of the dominant system (capitalism), but seeks to change the system and structure to be fairer. (Ronda, 2018).

Political economy theory of media is a social criticism approach that focuses on the relationship between economic structure and the dynamics of the media industry and the ideological content of media. Media institutions are seen as part of the economic system with close ties to the political system. Political economy theory of media finds neglect of the sector of a smaller and poorer potential audience, and there is often an unbalanced news media (McQuail, 2011).

Furthermore, according to McQuail, the media are always connected in one way or another with a strong political and economic power structure. Media that has economic value are objects of competition for control and access. The media are also subject to political, economic and legal regulations. In addition, the mass media is generally seen as an effective instrument for power with the potential capacity to exert influence in various ways. And the power of the mass media is not equally available to all groups and interests.

McQuail divides the power of mass media into two models. Namely, the dominant media model and the pluralist media model. The dominant media model is one that sees the media as a force representing other strong institutions. Media organizations in this view are often owned or controlled by a small number of powerful interests of similar types and objectives. These media propagate a limited and uniform view of the 
world shaped by the perspectives of powerful interests. The audience is restricted or conditioned to accept the worldview offered with little critical response. The result is to affirm or validate established power structures and to halt change by filtering out alternative voices. This model is consistent with the view of the media as a "cultural colonizer" or a means of political propaganda.

In contrast, the pluralist media model is the opposite of the dominant model which allows for more diversity and possibilities. No dominant and democratic control is possible. The pluralist media model is an idealized view of what the goals of liberalism and free markets are.

In the mass media industry, it is known as the gatekeeper. Gatekeepers are information selectors. Mass communication is carried out by several people in mass media organizations. They are the ones who make aselection of every incoming information to be broadcast to the public. Gatekeeper has the authority to expand or limit the information to be broadcast. All parties in the mass media organization can play a role as a gatekeeper. Among them are magazine publishers, newspaper editors, radio station managers, television news producers, journalists, and even telephone recipients at a mass media institution have the opportunity to become gatekeepers (Bungin, 2013).

The function of the gatekeeper is to evaluate the content of the news to suit the needs of the audience. But on the other hand, the gatekeeper can also be functioned by the authorities, both the political elite and the business elite, to fulfill interests and seek profit. In other words, in the name of the nation's interests, government officials can arrange the news according to their wishes. Meanwhile, in the name of economic growth, the business elite is doing the same thing.

In its development the mass media can also be utilized and has developed as an economic institution. The press industry sells information or news as a commodity. Even press companies are now comparable to banking companies or other service companies. The world of the press has now developed into an industry that requires large capital but also produces large profits that can be enjoyed by many people.

Information or events that occur in the field will go through a process to become news. Journalism is a process through which an information or event becomes news. A news item will go through the process of gathering information, processing and disseminating it. The same is done in television journalism. However, in television journalism or other electronic media, speed is no longer counted by days like print media news, but in hours, seconds or even broadcast instantly when the event occurs via live broadcast.

In the television media editorial team, the news management process will go through preproduction, production and post-production stages. Pre-production is an input process to get information or news. Production is the process of obtaining and processing information to become news, and post-production is the final touch of information processing and distribution or dissemination of news to the public. Thus, information has a long journey in management or management in the television media editorial.

This research wants to see the extent of the influence of the government, in this case the Ministry of Communication and Information, in the production process of Mata Indonesia feature news produced by Antara TV editorial. In brief, the conceptual framework that will be used by the author is as follows: 
Image 1. The Role of the Government and Between the Indonesian Eyes Production Process

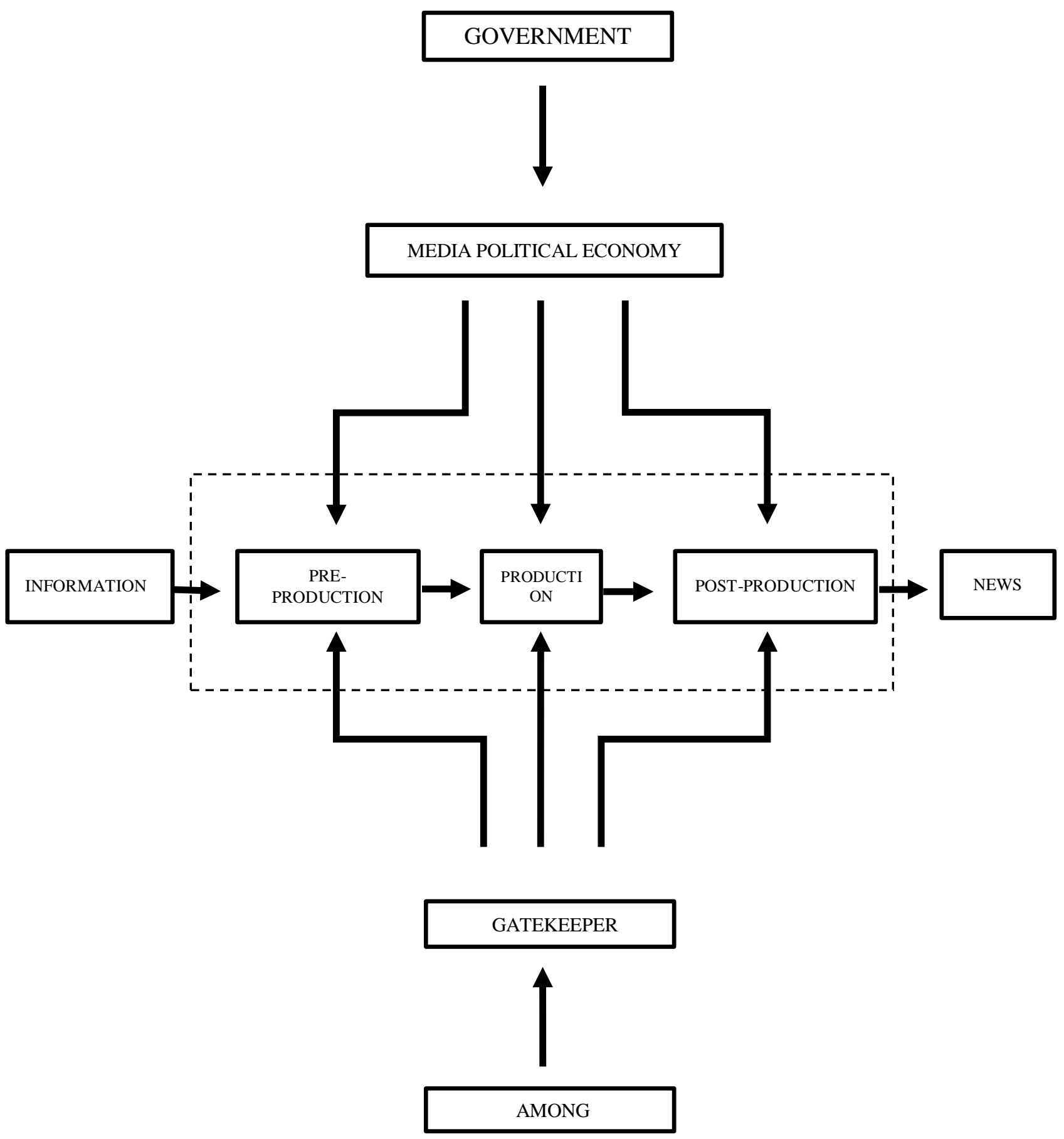




\section{RESEARCH METHODS}

In the production process of Mata Indonesia, Antara is accompanied by the Ministry of Communication and Information. This research was conducted to see the extent of the involvement of the Ministry of Communication and Information Technology in the production of the Indonesian Eye news conducted by Antara TV. Research was also conducted to find out what kind of Indonesian Mata products are produced in the juralistic lens of television news.

The research was conducted with a qualitative approach to the case study method. The main consideration of research is carried out with a qualitative approach because it aims to reveal phenomena that occur in the real world, through data collection as is (Syaefullah, 2015).

The case study method focuses on the specification of cases in an event, whether it includes individuals, cultural groups, or a portrait of life. A case study is a research strategy in which the researcher carefully investigates a program, event, activity, process, or group of individuals (Creswell, 2010).

This research was conducted by examining the stages of the production process for feature news, Antara TV Mata Indonesia. Data obtained by making direct observations to follow each stage of the production process. Starting from the pre-production stage, the production stage, to the post-production stage. Researchers see the role played by the government in this case the Ministry of Communication and Information Technology in every stage of the process. With the political economy theory approach to media, the researcher saw the extent of the involvement of the team appointed by the Ministry of Communication and Information in every stage of the production process. On the other hand, the researcher will also look at the strategy adopted by Antara TV's editorial staff in carrying out each stage of the process until the product is produced.

To complement the data obtained in the field, the researcher also conducted interviews with the parties involved in the production process of the Mata Indonesia feature. Interviews were conducted both with related parties in the Antara $\mathrm{TV}$ editorial team and the team involved from the Ministry of Communication and Information Technology.

The analysis used in this research is an analysis of each stage of the news production process on Antara TV. In each of these stages, it is seen to what extent the dominance of the Government influences editorial policies in producing Mata Indonesia feature products and how the policies and strategies applied by Antara TV editorial team

\section{RESULTS AND DISCUSSION}

The Antara National News Agency (LKBN) has an important history in the struggle of the nation and the establishment of the Indonesian state. Founded as Antara News Agency on December 13, 1937, Antara took a role in broadcasting the message of Indonesian independence on August 17, 1945 to the world. In 1962, Antara News Agency officially became the Antara National News Agency (LKBN) through Presidential Decree (Keppres) No.307 of 1962. Since then LKBN Antara has been under the direct supervision of the President of the Republic of Indonesia.

Antara continued, until July 18 2007, LKBN Antara officially became a State-Owned Enterprise (BUMN) under the Ministry of BUMN. As a BUMN, Antara changed its status to become a public company legal entity (Perum) through Government Regulation Number 40 of 2007. Since then, the name LKBN Antara has become the Public Company of the Antara National News Agency or Perum LKBN Antara.

News Service is the main or core product of LKBN Antara as a news agency. In this category, Antara produces news from all corners of the country, to serve customers in the mass media industry, especially print media both at home and abroad. This production activity is supported by 34 provincial bureaus, hundreds of 
correspondents, and 4 bureaus / correspondents abroad.

Antara TV was initiated in 2004 to answer the need for a diversity of news platforms, not just text and photos. Antara TV has been producing television content from the beginning until later adopting a terrestrial television working system. Antara TV then entered the construction of the dissemination of the Press Public Service Obligation (PSO) from the Ministry of Communication and Information.

Since 2008 the government has taken the initiative to produce PSO News, which has become a counterweight in dealing with media framing. Where there is an imbalance between news of controversy, horror, violence, sex, gossip, and glamority with inspirational news containing 3E1N (Educating, Enligthening, Empowering, and Nationalism). News PSO tries to avoid news production with a negative perspective and must choose a point of view in the spirit of 3E1N.

Mata Indonesia is one of the television programs produced by Antara TV editorial. Mata Indonesia is a feature story that contains more indepth information, a longer background story, and is presented in an attractive manner. Mata Indonesia contains reports on the results of coverage of an object or event that provide information, educate, entertain, convince, and inspire sympathy or empathy for the audience.

This 24-30minute program is intended to present a variety of useful information about state, government and community activities and at least contains one of the $3 \mathrm{E} 1 \mathrm{~N}$. Various government activities are elaborated into an in-depth coverage so as to provide understanding to the public about the activities carried out by the government. While the community activities presented can be in the form of positive activities or local wisdom that can inspire people in other areas.

The production process for a feature story takes a long journey. The production process of the Mata Indonesia program goes through several stages, namely the pre-production, production and post-production stages. Every week, a meeting on the agenda for the setting of the Antara editorial team is held with the team from the Ministry of Communication and Information Technology and the Presidential Staff Office. The meeting is intended to compile a coverage agenda for the next week and evaluate the results of the previous week's coverage. However, because the Mata Indonesia program is a timeless feature program, the production planning for Mata Indonesia is independent from the results of the weekly agenda setting meetings.

Featured news Mata Indonesia is designed as a news product that contains content about government activities and various community activities that inspire and educate people to always think critically and stay positive. In its implementation, the Ministry of Communication and Information Technology together with LKBN Antara set themes and grids that can guide the various PSO Press products produced.

As the holder of budget power for the PSO in the Press sector, the Ministry of Communication and Information has the authority to choose news which is financed or not. As with the political economy concept of media, the government has an interest in producing PSO news. But the goal remains how the public can get the information the government wants in the 3E1N corridor. While on the other hand, journalistic values are still carried out by Antara as the executor of the PSO product in the press sector.

In providing assistance the involvement of the Kominfo team is not only in guarding news content in terms of policies, but is also involved in technical matters of production. Various technical matters are supervised by the Kominfo team, including limited creativity. It is in accordance with the principles of the Political Economy of Media that in the production process of media products there is a struggle over how economic and political aspects affect the production and reproduction of culture as a mass media commodity. 
The government's dominance of Antara is very large. The government, as the full shareholder of BUMN LKBN Antara, has full power in determining the direction and policies that Antara takes in producing and disseminating information. On the other hand, the Government as a shareholder also has economic power against Antara, because most of Antara's funding still comes from the government through the PSO scheme. Thus, the Ministry of Communication and Information Technology also has the authority to determine the direction of reporting by Antara.

Each stage of production of Mata Indonesia is closely monitored by the Ministry of Communication and Information team. At the planning stage or in the pre-production stage, every proposal for coverage by Mata Indonesia must be consulted by Antara TV editorial with the Ministry of Communication and Information. The editorial suggestion of Antara TV will receive corrections, inputs and improvements so that it will remain a coverage that illustrates the success of the government. The coverage from the government side must be dominant. Coverage that shows the government's absence in society is not permitted.

Supervision by the Kominfo team continues at the production stage. The Kominfo team also accompanies the coverage process in the regions. Although not all of the coverage was accompanied by the Kominfo team. The participation of the Kominfo team also gave a warning to the coverage team in gathering information and conducting interviews in the field. All information and data obtained must describe the success or positive things about the government. On the other hand, if information or conditions are found describing the absence of the government, then it should not be the report of the Antara TV team's coverage.

In the post-production stage, the Kominfo team continues to supervise and provideassistance. The verification process for Mata Indonesia news becomes the final supervision, before the product is distributed. The Ministry of Communication and Informatics carries out verification of all news produced by Antara. Namely text news, photos, infographics and videos, including Mata Indonesia. At this stage the Kominfo team conducts a preview, or watches the final results of Mata Indonesia products. The Kominfo team makes corrections both from the news content to the technicality of preparing the news, such as image editing, narrative content, and presented graphics. Everything is done to ensure that the news presented is positive from the government, there is no information or pictures that show negative things to the government.

In order to get around this in producing Mata Indonesia, Antara TV editorial team is carrying out the gatekeeper function. This function is performed by all members of the editorial team involved. All team members from reporters and cameramen in the field, video editors, graphic / animators, producers, to executive producers carry out the gatekeeper function. Gatekeeping starts from planning, coverage in the field, script writing, video editing, post-production processing, to product distribution. All parties that play a role in the PSO news production process carry out the function of selecting and filtering various data and information obtained. All data and information are managed in such a way as to produce Mata Indonesia news in accordance with the wishes of the government.

Through this process, the final product produced through the cooperation of PSO in the press sector is Mata Indonesia feature news which is a journalistic work containing information about government activities. Mata Indonesia becomes journalistic work which is nothing but documentation about government activities.

\section{CONCLUSION}

From the research results, the following conclusions are obtained, first, not only 
overseeing policy and news content, the Ministry of Communication and Information Technology in its assistance and supervision is too far into technical matters. The Ministry of Communication and Information even helped organize everything into the technical production of Mata Indonesia news. Kominfo dominates the preparation of coverage plans or production designs (despro), the production process in the field and regulates the final product of Mata Indonesia.

Second, with the budgetary power and political power attached to Kominfo, Antara has implemented a strategy in producing PSO news. Between carrying out the gatekeeper function in carrying out the production of Indonesian Eyes. The gatekeeper function is carried out by every element involved in the production of Indonesian Eyes. The information presented must be in accordance with the wishes of Kominfo as the assignor. Any information must present a positive perspective for the government. This of course disturbed Antara's independence as a press institution. Because Antara no longer has the freedom to speak the true truth.

Third, instead of becoming news that educates, empowers, enlightens and builds people's nationalism, Mata Indonesia tends to be a form of socialization of government programs. The Indonesian eye is a product that contains information about the success of development carried out by the government. All information presented is the positive side of the government. The Indonesian eye product is like a documentary product of development activities by the government.

Based on these conclusions, the authors provide the following suggestions: first, in the production of feature news from Mata Indonesia, the government, in this case the Ministry of Communication and Information Technology, should not go too far in regulating the production process. Kominfo does not need to be involved in technical matters such as planning, production processes to determine the final product. The
Ministry of Communication and Information is sufficient to oversee general policies and ensure that the news content produced is content about the realities of society and contains positive things for all elements of the nation and state.

Second, as a press agency, Antara must uphold journalistic principles. Antara must be independent in carrying out its duties and functions of the press. Providing balanced information, reporting things that are truly beneficial to all components of society. Does not function itself as Government Public Relations (GPR). On the other hand, Antara must be able to escape dependence on the Ministry of Communication and Information, especially in terms of budget. Thus Antara can really carry out its function as a press agency.

Third, Indonesian Eyes apart from fulfilling the people's right to information, must also be a program that truly educates the public. The information presented is complete facts, not only from the government side but also facts that occur in society. Not only reporting the success of the government but also reporting the lives of other communities. Thus the community can understand very well what is happening in their environment, so that they can benefit from the information presented. On the other hand, the Indonesian eye must also be able to provide realist and positive news as well as balance the news framing carried out by other mass media.

\section{REFERENCES}

Al-Banjary, Syaefurrahman (2014), Teknik Reportase dan Produksi Berita Televisi, Yogyakarta: Deepublish
Harahap, Arifin (2018), Manajemen Pemberitaan dan Jurnalistik TV, Jakarta: Indeks Jakarata


Henshall, Peter, dan David Ingram (2000), Menjadi Jurnalis, Jakarta: Institut Studi Arus Informasi

Kovach, Bill, dan Tom Rosenstiel (2004), Elemen-elemen Jurnalisme: Apa Yang Seharusnya Diketahui Wartawan dan Yang Diharapkan Publik, Jakarta: Institut Studi Arus Informasi

Masduki (2007), Regulasi Penyiaran Dari Otoriter Ke Liberal, Yogyakarta: LkiS

Morissan (2011), Manajemen Media Penyiaran Strategi Mengelola Radio \& Televisi, Jakarta: Kencana Prenada Media Group

Sidik, Jafar M. (2019), Peta Jalan Antara TV

Subiakto, Henry, dan Rachmah Ida (2015), Komunikasi Politik, Media, dan Demokrasi, Jakarta: Prenadamedia Group

Tebba, Sudirman (2005), Jurnalistik Baru, Jakarta: Kalam Indonesia

Zaenuddin (2011), The Journalist Bacaan Wajib Wartawan, Redaktur, Editor \& Para Mahasiswa Jurnalistik, Bandung: Simbiosa Rekatama Media 